\title{
Pedagogical Aspects of the Ecosystem Approach to Professional Training of Staff for the Digital Transformation of the Region
}

\author{
Alexander N. Privalov 1*[ORCID 0000-0003-3311-0751], \\ Yuliya I. Bogatyreva 1[ORCID 0000-0003-4245-4943]
}

\author{
${ }^{1}$ Tula State Lev Tolstoy Pedagogical University, Tula, Russia \\ Privalov.61@mail.ru
}

\begin{abstract}
The article discusses the concept of professional training of future IT teachers as part of the human resources development ecosystem for the digital transformation of the region. The authors argue that school IT teachers are the most important part of human resources necessary for digital transformation at the regional level. To solve the problem of training human resources for the implementation of digital transformation, it is necessary to build a flexible, network, multi-level system for training qualified staff, taking into account regional needs. The research purpose is to define the features of training IT teachers as a part of regional human resources necessary for digital transformation inside the educational ecosystem, to make the training a part of the ecosystem, to determine their mutual influence and possible directions of further development. This purpose is achieved through the following objectives: analyzing the content of the "educational ecosystem" phenomenon in regards to the staff training for the digital transformation of the region, including the innovative training of IT teachers; identifying the components of the ecosystem, training staff for the digital transformation of the region, including the innovative training of IT teachers; developing a number of questionnaires to determine the maturity level of the university as the core of the ecosystem. The research results are used to define the structure of the ecosystem necessary for the human resources development in regards to digital transformation of the region. The authors single out five components to analyze the educational ecosystem of professional training for the digital transformation of the region. The ecosystem for the development of human resources necessary for the region digital transformation has been created in Tula State Lev Tolstoy Pedagogical University. The article presents a set of diagnostic tools for assessing the maturity level of the university as the core of the ecosystem.
\end{abstract}

Keywords: digital transformation, educational ecosystem, future IT teachers, education, innovative training

\section{INTRODUCTION}

The society development is presently characterized by the expanding processes of digital transformation $[1,2]$. The rapid spread of digital technologies, their deep penetration into all spheres of life predetermines the interest of researchers in various aspects of this phenomenon, including in the field of staff training.

IT teachers are those educators who introduce students to the digital world in a special educational discipline - Informatics and ICT, therefore, the involvement of school leavers in digital technologies and the general digital industry depends on the level of professional training of teachers of informatics.

The practical implementation of the National Program revealed a significant problem of a shortage of staff with relevant digital competencies.

Training of staff and human resources is related to the organization of large-scale transformations, starting from the school level to the level of professional retraining of already working people.

To solve the problem of training human resources for the implementation of digital transformation tasks, it is necessary to build a 
flexible, network, multi-level system for training qualified staff, taking into account regional needs.

The training system should be based on innovations:

- deferred choice, i.e. the ability to determine the education direction after the end of the second year, and not during the admission;

- the paradigm of training students who will be able to flexibly fit into the labor market due to a wide educational background.

Today, a noticeable trend in the development of educational organizations engaged in professional training is the expansion of their ties with the outside world, including society/region, companies in the real sector of the economy, other universities, colleges, schools. This trend is confirmed by world practice. For example, the European Commission requires all young people to "benefit from at least one practical business experience before dropping out of compulsory education"'[3].

This research will consider the training of school IT teachers as a source and as a tool for training staff for digital transformation at the regional level, since it means a broader view of education and involves a wide range of participants both inside the educational organization and outside it.

The structure of the ecosystem for training staff for digital transformation is shown in Figure 1.

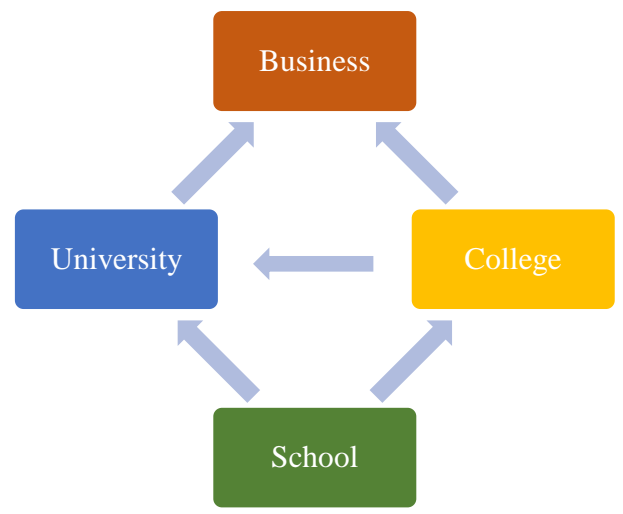

Figure 1. Ecosystem for training for digital transformation

Source: Compiled by the authors

A conceptual analogy could be drawn: in ecology, ecosystems consist of a systemic community of living organisms that interact with inanimate elements of the environment [4-6]. In the world of education, ecosystems can be defined as the total variety of actors (i.e. living species) and all non-living elements used for education through teaching and learning. The full spectrum of participants includes people within the educational organization (mainly teachers, administrators, students, and other staff) as well as society outside the educational organization (entrepreneurs, associations, institutions, parents, families, friends and individuals, etc.). Inanimate (abiotic) elements within this environment are represented by all available material resources (buildings, classrooms, external objects, tools, IT resources, etc.); they affect the nature of the interaction between students and the rest of society. All of these populations are networking.

We use the concept of ecosystems as a metaphor for modeling the dynamics of the staff training environment for digital transformation at the regional level $[4,7,8]$. Within the framework of the concept, teachers are provided with specific tools and methodologies that allow them to create and / or transform appropriate learning environments within the educational process. The aim is to enable educational leaders and educational decision-makers to design and analyze a learning environment that best suits their individual context and aspirations.

Ecosystems function in a complex environment [9]. Ecosystem participants interact in a specific geographic area, and their behavior, reactions and actions are influenced by a set of social, political, cultural and economic conditions. This process gradually creates an ecosystem of the organization in our case, the educational one. Therefore, to understand the constituent elements of ecosystem training staff for the digital transformation, we need to understand their environment. This implies at least two subsequent levels of understanding, of which the first level requires making a list of its elements. Then, at the second level of understanding, one needs to look at how these components interact.

Using a dynamic approach to the educational context, it can be argued that it is not enough to know the number of living components (internal and external participants, trainers, etc.), as well as material resources (technical capabilities of the class, teaching materials).

It is equally important to look at the dynamics between the actors and the means. In this case, when designing an educational ecosystem, it is necessary to analyze why and how relationships are built, for example, between teachers and students, between students and external actors, or how teaching materials, digital infrastructure and aids are used to support education. 


\section{MATERIALS AND METHODS}

The research purpose is to determine the features of training IT teachers as part of the regional human resources necessary for digital transformation inside the educational ecosystem, to determine the main components of the ecosystem, their mutual influence, and possible directions of progress.

The research purpose defines the major research objectives:

1) to analyze the content of the "educational ecosystem" phenomenon in relation to the training of staff necessary for the digital transformation of the region, including the innovative training of IT teachers;

2) to identify the component composition of the ecosystem of training staff for the digital transformation of the region, including the innovative training of IT teachers;

3) to develop a set of tests for determining the maturity level of the university - as the core of the ecosystem.

The methodological basis of this research consists of conceptual ideas about professional training for the digital economy at various levels and in diverse forms.

The research dwells on the theoretical and applied research results of Russian and foreign scientists and professionals in the field of educational systems, pedagogy and digital technologies.

Of particular interest was the analysis of the modern system of staff training for the digital economy in Russia; the relevant results have been discussed by the Russian scholars (Y. Bogatyreva, A. Privalov, V. Romanov, M. Lapina) earlier in [10] and by A.V. Vershinina [11], as well as by the Western researchers M. Olssen and M. Peters [12]. We also used the data on the specific features of teaching subjects for digital skills development that were identified by A.G. Burda and G.P. Burda [13].

To properly describe the learning environment within and outside the organization dealing with digital transformation training it is necessary to deepen the understanding of how organizations function in their respective contexts.

Having studied the conceptual path of "ecosystems" development, we could build a structured framework for considering the educational environment (Figure 2).
To study the educational ecosystem of professional training of staff for the digital transformation of the region, it is proposed to distinguish five components:

- the educational program/programs which is/are being implemented in the ecosystem;

- communication links between the elements of the ecosystem;

- digital culture of ecosystem:

- pedagogical approaches used in the ecosystem:

- educational spaces of the ecosystem.

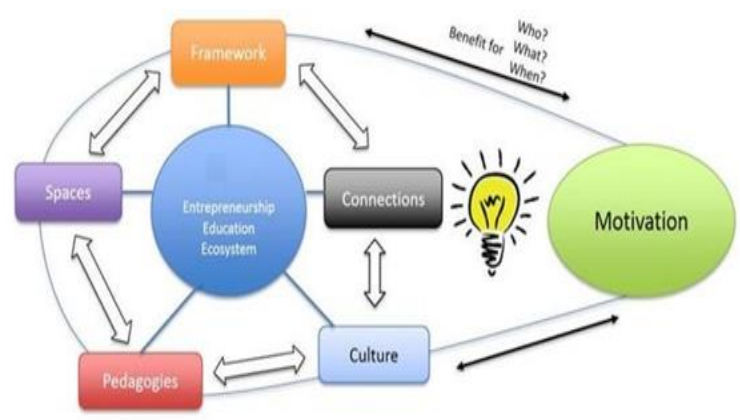

Figure 2. Education Ecosystem (EE)

Source: [5]

It is very important to perceive the dynamics of mutual influence. Each of these components is associated with specific actors and means. But only by considering and connecting all the components one can get a complete, vivid picture of the environment, that allows scaling up and down in accordance with the needs of the educational organization.

Each educational ecosystem is different from the other as it involves different actors in different contexts. To form a conceptual picture of the existing ecosystem of staff training and its relationship with the environment, a questionnaire consisting of five questions is proposed (Table 1).

Extrinsic and intrinsic motivation affects each other.

Social recognition of the award can nudge educators to develop digital competency initiatives.

The intrinsic motivation of IT teachers and the resulting outstanding initiatives can inspire colleagues (i.e. they create intrinsic motivation) or other educational and community policy organizations to develop similar actions (i.e. create extrinsic motivation). 
Table 1. Questionnaire "What is the ecosystem of staff training?

\begin{tabular}{|c|c|}
\hline $\mathbf{s}$ & ed \\
\hline $\begin{array}{lr}\text { What } & \text { training } \\
\text { programs } & \text { are } \\
\text { implemented in the } \\
\text { ecosystem? }\end{array}$ & n related \\
\hline 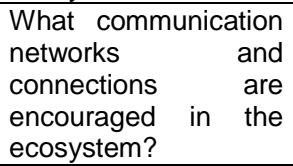 & $\begin{array}{l}\text { Analyze ho } \\
\text { elements } \\
\text { the univer } \\
\text { actors }\end{array}$ \\
\hline $\begin{array}{l}\text { What kind of digital } \\
\text { culture is your } \\
\text { ecosystem creating? }\end{array}$ & $\begin{array}{l}\text { ised on values, } \\
\text { hnology. They } \\
\text { the ecosystem } \\
\text { it }\end{array}$ \\
\hline $\begin{array}{l}\text { What pedagogical } \\
\text { solutions r are } \\
\text { preferred to stimulate } \\
\text { learning? }\end{array}$ & $\begin{array}{l}\text { Analyze existing and emerging } \\
\text { pedagogical techniques, methods } \\
\text { and tools, and preferred } \\
\text { pedagogical solutions to stimulate } \\
\text { learning }\end{array}$ \\
\hline $\begin{array}{l}\text { What learning space } \\
\text { is education } \\
\text { embedded in? }\end{array}$ & $\begin{array}{l}\text { Analyze the physical and virtual } \\
\text { spaces available to students in } \\
\text { your institution and possible } \\
\text { barriers to access }\end{array}$ \\
\hline
\end{tabular}

Source: Compiled by the authors

The problematic issues that need to be addressed concern the benefits and implications for the various actors in the system and the nature of these benefits.

\section{RESULTS}

There are two main levels in the ecosystem that determine the structure of learning:

- the "teacher level" with the question - Does the educational organization as the part of the ecosystem contribute to finding the new ways of training for its teachers?

- the "student level" with the question - What educational goals are set for the students?

Considering the training of future IT teachers, one can notice that at both levels the educational objectives can be twofold, that is, the activity can be focused on the development of pedagogical competencies and /or on the development of digital thinking.

A good example of developing digital competencies of teachers is the project of establishing the Institute of Advanced Information Technologies (hereinafter - IPIT) in Tula State Lev Tolstoy Pedagogical University, which promotes the innovative training of IT teachers and involves IT industry practitioners in improving the qualifications of teachers and the digital tech project solutions.

The goal is to integrate new technologies and innovations developed by universities, by research centers and companies into the professional training of future teachers.

Digital thinking activities aim to create social and economic value. In some cases, these activities do not go beyond the organizational framework of the curriculum. For example, students make projects aimed at the development of digital products to solve the social problems of the region.

In other cases, the development of an idea and the creation of a digital product connect students and teachers with other project participants inside and outside the university. The latter approach connects students and the entire university much more with the local environment and creates intensive relationships necessary for a university with an appearance.

Activities for the digital thinking development are aimed at the development of students' personalities and of study groups. Despite the fact that it can take place within the framework of a project or a startup, the main focus is on the development of individual digital competencies. These activities stimulate cognitive and metacognitive learning, which allows the students to activate their own learning abilities and thus selfregulate their learning process. The students are encouraged to reflect on their own efforts; they are taught what should be done to make them a reality. This is especially important for the university, as it encourages students and teachers to actively seek and use funds outside the university environment.

One can say that at the university, as the core of an educational ecosystem focused on the surrounding social space, ecosystem participants take part in various stages of education; students are supported in creating value based on the needs of society and / or region. Thus, collaborative processes are emerging in the IT teacher training ecosystem. To assess the participation of partner organizations of the ecosystem, a questionnaire was developed (Table 2).

We will consider the communication links between the elements of the ecosystem from the standpoint of network interaction. These connections and network structures created by a university with ecosystem partners can be different in the nature and intensity of relations, for example, short-term cooperation within the framework of a project, longterm cooperation within the framework of joint implementation of an educational program, etc.

When looking at the education actors, we clearly observe two forms of networking for access to 
human resources. For some educational organizations, communication links, relationships, networks are created exclusively within the university environment (between university consortia, teachers of various subjects or a university within one network). However, some HEIs have developed a strong and wide network outside the organizational boundaries of the university, spanning regional, national and international levels.

Table 2. Self-reflection questionnaire about the training program

\begin{tabular}{|c|c|c|c|}
\hline $\begin{array}{c}\text { Key } \\
\text { Questions }\end{array}$ & Who? & How? & $\begin{array}{c}\text { What can } \\
\text { be } \\
\text { Changed? }\end{array}$ \\
\hline $\begin{array}{l}\text { Do partners } \\
\text { participate in } \\
\text { the } \\
\text { development } \\
\text { of educational } \\
\text { activities? }\end{array}$ & $\begin{array}{l}\text { Teachers, } \\
\text { administ- } \\
\text { ration, } \\
\text { students, } \\
\text { partners }\end{array}$ & $\begin{array}{l}\text { Personal } \\
\text { contacts, } \\
\text { partnership } \\
\text { agreement at } \\
\text { the educational } \\
\text { institution level, } \\
\text { etc. }\end{array}$ & $\begin{array}{l}\text { For } \\
\text { example, } \\
\text { contacts of } \\
\text { students } \\
\text { and } \\
\text { partners } \\
\text { could be } \\
\text { used more } \\
\end{array}$ \\
\hline $\begin{array}{l}\text { Do partners } \\
\text { participate in } \\
\text { organizing } \\
\text { and } \\
\text { conducting } \\
\text { educational } \\
\text { events? }\end{array}$ & $\begin{array}{l}\text { Teachers, } \\
\text { administ- } \\
\text { ration, } \\
\text { students, } \\
\text { partners }\end{array}$ & $\begin{array}{l}\text { For example, } \\
\text { participation in } \\
\text { hackathons, } \\
\text { competitions, } \\
\text { the } \\
\text { implementation } \\
\text { of educational } \\
\text { projects }\end{array}$ & $\begin{array}{l}\text { For } \\
\text { example, } \\
\text { expand } \\
\text { interaction }\end{array}$ \\
\hline $\begin{array}{l}\text { Do the } \\
\text { students get } \\
\text { any support in } \\
\text { implementing } \\
\text { projects } \\
\text { based on the } \\
\text { needs of the } \\
\text { community } \\
\text { and / or } \\
\text { region? }\end{array}$ & $\begin{array}{l}\text { Teachers, } \\
\text { administ- } \\
\text { ration, } \\
\text { students, } \\
\text { partners }\end{array}$ & $\begin{array}{l}\text { For example, } \\
\text { technical } \\
\text { support is } \\
\text { provided to } \\
\text { students in the } \\
\text { implementation } \\
\text { of projects }\end{array}$ & $\begin{array}{l}\text { For } \\
\text { example, } \\
\text { expand } \\
\text { support }\end{array}$ \\
\hline
\end{tabular}

Source: Compiled by the authors

For example, IPIT organized networking with companies in the IT sector of the economy operating both in the region and within the Russian Federation.

For universities that offer educational activities for potential IT industry practitioners, it is also important to establish institutional contacts with local business support organizations.

Personal contacts can certainly contribute to this, but they cannot replace the institutional relationships that are necessary to exchange resources and create a common ecosystem.

Practice shows that education at a university, focused on broad interaction with business and educational partners, is not tied to its physical boundaries and that the difference between an "internal" and "external" university practically disappears.
To conduct self-reflection on this issue, a questionnaire is proposed (Table 3).

Table 3. Self-reflection questionnaire about the participation in partnerships and consortia

\begin{tabular}{|c|c|c|c|}
\hline $\begin{array}{c}\text { Key } \\
\text { Questions }\end{array}$ & Who? & How? & $\begin{array}{c}\text { What can } \\
\text { be } \\
\text { Changed? }\end{array}$ \\
\hline $\begin{array}{l}\text { Are educators } \\
\text { actively } \\
\text { involved in } \\
\text { local } \\
\text { partnerships } \\
\text { and do they } \\
\text { integrate it } \\
\text { into their } \\
\text { programs? }\end{array}$ & $\begin{array}{l}\text { Teachers, } \\
\text { administ- } \\
\text { ration, } \\
\text { students, } \\
\text { partners }\end{array}$ & $\begin{array}{l}\text { Partnership } \\
\text { agreement } \\
\text { at the level } \\
\text { of the } \\
\text { university, } \\
\text { city, etc. }\end{array}$ & $\begin{array}{l}\text { For example, } \\
\text { increase the } \\
\text { participation } \\
\text { of educators } \\
\text { in local } \\
\text { partnerships }\end{array}$ \\
\hline $\begin{array}{l}\text { Are students } \\
\text { involved, } \\
\text { encouraged } \\
\text { and } \\
\text { supported in } \\
\text { educational } \\
\text { projects } \\
\text { outside the } \\
\text { university? }\end{array}$ & $\begin{array}{l}\text { Teachers, } \\
\text { administ- } \\
\text { ration, } \\
\text { students, } \\
\text { partners }\end{array}$ & $\begin{array}{l}\text { For } \\
\text { example, } \\
\text { participation } \\
\text { in consortia, } \\
\text { creation of } \\
\text { network } \\
\text { educational } \\
\text { programs }\end{array}$ & $\begin{array}{l}\text { For example, } \\
\text { expand } \\
\text { interaction } \\
\text { with other } \\
\text { universities }\end{array}$ \\
\hline $\begin{array}{l}\text { Do students } \\
\text { get any } \\
\text { support in } \\
\text { implementing } \\
\text { projects } \\
\text { based on the } \\
\text { needs of the } \\
\text { community } \\
\text { and / or } \\
\text { region? }\end{array}$ & $\begin{array}{l}\text { Teachers, } \\
\text { administ- } \\
\text { ration, } \\
\text { students, } \\
\text { partners }\end{array}$ & $\begin{array}{l}\text { For } \\
\text { example, } \\
\text { students are } \\
\text { credited with } \\
\text { points } \\
\text { scored in } \\
\text { electronic } \\
\text { courses in } \\
\text { other } \\
\text { universities }\end{array}$ & $\begin{array}{l}\text { For example, } \\
\text { expand } \\
\text { student } \\
\text { support }\end{array}$ \\
\hline
\end{tabular}

Source: Compiled by the authors

University educational spaces for learning can be located on two axes (Figure 3). The horizontal axis represents the localization of those learning spaces, which in extreme cases can be either fully integrated into the university or completely externalized, i.e. located exclusively outside the university premises. The vertical axis represents the management of these learning spaces, which can either be completely managed and created by the university or be fully managed by students.

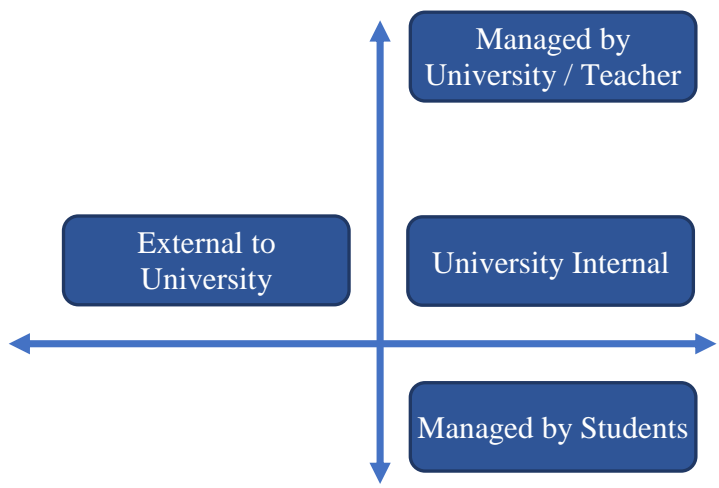

Figure 3. Dimensions of learning space Source: [5] 
To review the current situation at the university and to define the area for possible changes, it is proposed to use the test with the questions "as it is now" and "as it could be" (Table 4).

Table 4. Self-reflection questionnaire on educational spaces

\begin{tabular}{|l|l|l|}
\hline \multicolumn{1}{|c|}{ Key Questions } & $\begin{array}{c}\text { As it is } \\
\text { Now }\end{array}$ & $\begin{array}{c}\text { As it } \\
\text { Could be }\end{array}$ \\
\hline $\begin{array}{l}\text { Students and teachers collaborate } \\
\text { to create teaching materials }\end{array}$ & & \\
\hline Space for learning & & \\
\hline $\begin{array}{l}\text { Flexibility and modular infrastructure } \\
\text { to adapt the space to educational } \\
\text { needs }\end{array}$ & & \\
\hline $\begin{array}{l}\text { Balance between the learning } \\
\text { space inside the university and } \\
\text { outside it }\end{array}$ & & \\
\hline $\begin{array}{l}\text { A variety of students majoring in } \\
\text { different profiles (especially } \\
\text { students majoring in two different } \\
\text { fields) }\end{array}$ & & \\
\hline $\begin{array}{l}\text { Collaborative learning spaces to } \\
\text { facilitate exchange through this } \\
\text { diversity }\end{array}$ & \\
\hline
\end{tabular}

Source: Compiled by the authors

The cases of establishing the so-called "Boiling Points" in universities exemplify partially externalized spaces or spaces with a high degree of internal transparency. This approach provides flexibility and openness that extends to teachers and students. In this case, we observe modular and transparent forms of learning spaces that allow interaction and exchange of information at all social levels. External participants can easier enter and collaborate on the same level than students. In addition, some universities allow students to "own" the learning space through a self-organized design process.

Such ecosystem component as "digital culture" can be defined as "the ability of universities and external actors to interact, create, share and develop a common "language". Language is taken in a broader sense; it affects general meanings and behavior, as well as the general vision of society. Digital culture influences the way students - during and after their studies - will interact with the world outside the university.

When the goal is to create a shared digital culture in an educational ecosystem, it is important to take into account the overall learning objectives and the university's vision statement in order to determine the most appropriate actions to create that kind of culture. Each university establishes its own digital culture with a focus on different values and activities. Some universities are developing digital competencies with a focus on one or more of the following factors:
- building an individual worldview and awareness of personal resources to transform the world with the help of digital technologies;

- focus on creating digital products as social value; promoting digital culture.

The digital culture of the university can be understood as the ability of the university and external actors to interact and create, share and develop a common "language", while the language includes common meanings and behaviors, as well as a common vision of society. To conduct selfreflection on this issue, a test is proposed (Table 5).

Table 5. Self-reflection questionnaire on digital culture of ecosystem

\begin{tabular}{|c|c|c|c|}
\hline $\begin{array}{c}\text { Key } \\
\text { Questions }\end{array}$ & Who? & How? & $\begin{array}{l}\text { What Could } \\
\text { be } \\
\text { Changed? }\end{array}$ \\
\hline $\begin{array}{l}\text { Do you know } \\
\text { the major } \\
\text { stakeholders } \\
\text { in the regional } \\
\text { IT industry } \\
\text { and their } \\
\text { respective } \\
\text { roles? }\end{array}$ & $\begin{array}{l}\text { Teachers, } \\
\text { administ- } \\
\text { ration, } \\
\text { students, } \\
\text { partners }\end{array}$ & $\begin{array}{l}\text { The } \\
\text { establishing } \\
\text { of a city } \\
\text { educational } \\
\text { portal is } \\
\text { discussed in } \\
\text { class }\end{array}$ & $\begin{array}{l}\text { For example, } \\
\text { expand } \\
\text { students' } \\
\text { participation } \\
\text { in the creating } \\
\text { educational } \\
\text { content }\end{array}$ \\
\hline $\begin{array}{l}\text { Does the } \\
\text { university } \\
\text { view local } \\
\text { partnerships } \\
\text { as a valuable } \\
\text { contribution to } \\
\text { education? }\end{array}$ & $\begin{array}{l}\text { Teachers, } \\
\text { administ- } \\
\text { ration, } \\
\text { students, } \\
\text { partners }\end{array}$ & $\begin{array}{l}\text { For example, } \\
\text { the } \\
\text { participation } \\
\text { of a university } \\
\text { in a } \\
\text { consortium } \\
\text { with regional } \\
\text { IT companies }\end{array}$ & $\begin{array}{l}\text { For example, } \\
\text { expand } \\
\text { interaction } \\
\text { with other } \\
\text { universities } \\
\text { through } \\
\text { network } \\
\text { programs }\end{array}$ \\
\hline $\begin{array}{l}\text { Does } \\
\text { education } \\
\text { deal with } \\
\text { issues } \\
\text { relevance to } \\
\text { the } \\
\text { community / } \\
\text { region? }\end{array}$ & $\begin{array}{l}\text { Teachers, } \\
\text { administ- } \\
\text { ration, } \\
\text { students, } \\
\text { partners }\end{array}$ & $\begin{array}{l}\text { For example, } \\
\text { students are } \\
\text { credited with } \\
\text { points scored } \\
\text { in electronic } \\
\text { courses in } \\
\text { other } \\
\text { universities }\end{array}$ & $\begin{array}{l}\text { For example, } \\
\text { expand } \\
\text { support }\end{array}$ \\
\hline
\end{tabular}

Source: Compiled by the authors

The next component of the ecosystem is "pedagogical approaches".

Along with the well-known, classical approaches, the ecosystem can offer innovative experimental teaching methods that are used as a bridge between external partners, teachers and students, actions that induce students to action.

With regard to the pedagogical solutions of the universities, focused on the external interaction track, we have identified some common features. The strength of the universities, which form the core of the educational ecosystem, is the systematic use of collaborative approaches. In the learning process, cooperation between students and teachers is 
encouraged, and, most importantly, students are encouraged to actively seek information and become involved in IT projects outside the classroom educational process. This can be either a one-time visit to the company or a long professional internship in the company.

Another pedagogical technique is the solution of situational tasks close to real life. From a pedagogical perspective, developing an IT product to address the social challenge of a region can be a very stimulating learning experience that can reduce fears of social bonds and failure in the "real world". For example, students of the Tula IPIT are developing information systems not only of the educational type, but also for helping people with disabilities. Projects are student-led; students select, contact, and involve external actors in the training.

Table 6. Self-reflection questionnaire on pedagogical approaches in the ecosystem

\begin{tabular}{|c|c|c|c|}
\hline $\begin{array}{c}\text { Key } \\
\text { questions }\end{array}$ & Who? & How? & $\begin{array}{c}\text { What could } \\
\text { be } \\
\text { changed? }\end{array}$ \\
\hline $\begin{array}{l}\text { Are partners } \\
\text { involved in } \\
\text { defining } \\
\text { learning } \\
\text { outcomes and } \\
\text { assessment } \\
\text { approaches? }\end{array}$ & $\begin{array}{l}\text { Teachers, } \\
\text { administ- } \\
\text { ration, } \\
\text { students, } \\
\text { partners }\end{array}$ & $\begin{array}{l}\text { The shutdown } \\
\text { of the local } \\
\text { factory and its } \\
\text { consequences } \\
\text { are discussed } \\
\text { in class }\end{array}$ & $\begin{array}{l}\text { For } \\
\text { example, } \\
\text { increase the } \\
\text { participation } \\
\text { of teachers } \\
\text { in local } \\
\text { partnerships }\end{array}$ \\
\hline $\begin{array}{l}\text { Is experiential } \\
\text { learning used } \\
\text { as a bridge } \\
\text { between } \\
\text { external } \\
\text { partners, } \\
\text { teachers and } \\
\text { students? }\end{array}$ & $\begin{array}{l}\text { Teachers, } \\
\text { administ- } \\
\text { ration, } \\
\text { students, } \\
\text { partners }\end{array}$ & $\begin{array}{l}\text { For example, } \\
\text { participation in } \\
\text { consortia, } \\
\text { creation } \\
\text { network } \\
\text { educational } \\
\text { programs }\end{array}$ & $\begin{array}{l}\text { For } \\
\text { example, } \\
\text { expand } \\
\text { interaction } \\
\text { with other } \\
\text { universities }\end{array}$ \\
\hline $\begin{array}{l}\text { Are students } \\
\text { encouraged } \\
\text { and } \\
\text { supported to } \\
\text { implement } \\
\text { projects } \\
\text { based on their } \\
\text { interests, } \\
\text { values and } \\
\text { ideas? }\end{array}$ & $\begin{array}{l}\text { Teachers, } \\
\text { administ- } \\
\text { ration, } \\
\text { students, } \\
\text { partners }\end{array}$ & $\begin{array}{l}\text { For example, } \\
\text { students are } \\
\text { credited with } \\
\text { points scored } \\
\text { in electronic } \\
\text { courses in } \\
\text { other } \\
\text { universities. }\end{array}$ & $\begin{array}{l}\text { For } \\
\text { example, } \\
\text { expand } \\
\text { support }\end{array}$ \\
\hline $\begin{array}{l}\text { Is the positive } \\
\text { impact of } \\
\text { students' } \\
\text { personal } \\
\text { activities and } \\
\text { commitments } \\
\text { on society / } \\
\text { region } \\
\text { encouraged } \\
\text { and } \\
\text { supported? }\end{array}$ & $\begin{array}{l}\text { Teachers, } \\
\text { administ- } \\
\text { ration, } \\
\text { students, } \\
\text { partners }\end{array}$ & $\begin{array}{l}\text { For example, } \\
\text { students } \\
\text { receive credit } \\
\text { points in the } \\
\text { discipline if a } \\
\text { project is done } \\
\text { in the interests } \\
\text { of the region }\end{array}$ & $\begin{array}{l}\text { For } \\
\text { example, } \\
\text { develop } \\
\text { forms } \\
\text { support }\end{array}$ \\
\hline
\end{tabular}

Source: Compiled by the authors

For the university which is the core of the ecosystem, the individual leadership is also important; the teacher leads the implementation of one type of activity of the entire strategy to establish a digital culture in the educational ecosystem. These should be people with different innovative views on education. They use this perspective to develop and promote new approaches and ways to stimulate mastering digital transformation competencies.

Another way that can be based on individualized leadership is collaborative leadership. In this case, all internal and external stakeholders participate in the joint development and implementation of particular events or the university digital culture strategies. Sometimes, the faculty and university management interacting with industrial partners can go beyond the scope of standard educational activities. They involve many participants, and they do not always correspond to the existing organizational boundaries and the framework of the university. Sometimes this activity establishes new organizational forms outside the university, for example, small innovative enterprises.

To conduct self-reflection on this issue, a questionnaire is proposed (Table 6).

\section{DISCUSSION}

The main research result is a paradigm for training staff for digital transformation as a part of an appropriate ecosystem, which includes, along with the university as the ecosystem core, other educational organizations (schools, colleges), enterprises of the real sector of the economy, and the regional social environment structures.

This means a new look at the very process of professional training, in which many actors are involved, their interaction is carried out not only on the internal, but also on the external circuit of the university.

The research complements the findings of some scholars who deal with quality improvement and professional training, including teaching staff training.

For example, A.K. Murzayeva in her dissertation argues that today there is "a certain imperfection of educational mechanisms that should ensure the relationship between higher educational institutions and the labor market" [14].

The proposed ecosystem-based approach is not limited to the framework of training for digital transformation; it can be applied to other relevant areas. 
Consequently, the further research is possible not only on the issues of training "digital" personnel, the definition and substantiation of methods, technologies and best practices, but also on the training of other professionals.

\section{CONCLUSION}

The ecosystem of professional training of staff for digital transformation of the region, including IT teachers, is an important element of the regional digital transformation system.

The university, as the core of the ecosystem, is a habitat that allows interaction between students, teachers and the community of people interested in the wide digitalization of the environment. The nature of these interactions is crucial for fostering creativity, trust, and freedom of development and transformation. The more internal and external stakeholders are involved in maintaining and developing the ecosystem of region digital transformation, the more dynamic and attractive education will become.

The environment can be considered a "third teacher" (after parents and teachers), which must be designed in such a way as to encourage new experiences, exploration, initiative and creativity.

Thus, acting in an ecosystem requires us to (i) be aware of its existence; (ii) be aware of all the parties involved - inside and outside the university - that can potentially affect digital transformation learning; (iii) create a collaborative project - with and between all these stakeholders - in which teachers will play a supportive and/or expediting role; and regularly and collectively evaluate the results of these collaborative actions - both in terms of learning outcomes and in terms of the development of digital competence at the university.

Consequently, an ecosystem cannot be created or developed solely on a top-down basis. Evidently, the role of a public policy coordinator is clear, but it is the interaction of all internal and external actors that will become a key success factor for an effective ecosystem of training staff with digital transformation competencies.

\section{ACKNOWLEDGMENTS}

The article was written with financial support by the Ministry of Education of the Russian Federation of the topic "Innovative approaches to professional training of teachers of informatics in the context of digitalization of society" (contract No. 073-03-2021$019 / 2$ of 21.07.2021).

\section{AUTHORS' CONTRIBUTIONS}

The authors made an equal contribution to the study: collection and analysis of material; definition of goals and objectives, research methods; formulation and scientific substantiation of conclusions, registration of key research results in the form of an article.

\section{REFERENCES}

[1] On approval of the program "Digital Economy of Russian Federation: [dec. of RF Government of 28.07.2017 No 1632-r] Collection of RF Legislation. 2017. Aug., 07 No 32. p. 5138 [Ob utverzhdenii programmy "Tsifrovaya ekonomika Rossiyskoy Federatsii": [rasp. Pravitelstva RF ot 28.07.2017 № 1632-r]. Sobraniye zakonodatel'stva RF. 2017. 07 avg. No 32. st. 5138]. (In Russ.). Retrieved from http://government.ru/docs/28653/

[2] Passport of National Porject National Program "The Digital economy of Russian Federation", Ministry of Digital Development, Communication and Mass Media [Pasport natsional'nogo proyekta Natsional'naya programma "Tsifrovaya ekonomika Rossiyskoy Federatsii”, Ministerstvo tsifrovogo razvitiya, svyazi i massovykh kommunikatsiy Rossiyskoy Federatsii], 2017. (In Russ.). Retrieved from https://digital.gov.ru/uploaded/files/natsionalnay a-programma-tsifrovaya-ekonomika-rossijskojfederatsii_NcN2nOO.pdf

[3] European Commission. Rethinking Education: Investing in skills for better socio-economic outcomes, 2012. Retrieved from https://eose.org/ressource/commissioncommunication-rethinking-education-investingin-skills-for-better-socio-economic-outcomes/

[4] F.S. Chapin, E.S. Zavaleta, et al., "Consequences of changing biodiversity", Nature, 2020, vol. 405, pp. 234-242.

[5] S. Mueller, O. Toutain, "The Outward Looking School and its Ecosystem", Entrepreneurialism360, Thematic Paper, OECD and European Commission, 2015.

[6] S. Trudgill, "Tansley, A.G. 1935: The use and abuse of vegetational concepts and terms. Ecology 16, 284 307”, Progress in Physical Geography, 2007, vol. 31, pp. 517-522. DOI: 10.1177/0309133307083297

[7] G.C. Daily, S. Polasky, et al., "Ecosystem 
services in decision making: time to deliver", Frontiers in Ecology and the Environment, 2009, vol. 7, pp. 21-28.

[8] E. Morin, N. Hulot, "L'an I de l'ère écologique: La Terre dépend de l'homme qui dépend de la Terre", Paris: Editions Tallandier, 2007. (In France).

[9] B.R. Clark, "Sustaining Change in Universities: Continuities in Case Studies and Concepts", Tertiary Education and Management, 2003, vol. 9, pp. 99-116.

[10] Y. Bogatyreva, A. Privalov, V. Romanov, M. Lapina, "Development of competences of the digital economy of teachers in the conditions of digital transformation education", CEUR Workshop Proceedings this link is disabled, 2020, vol. 2861, pp. 147-157.

[11]A.V. Vershinina, E.N. Koshkina, et al., "Analysis of System of Training Staff for Digital Economy on Russia" [Analiz sistemy podgotovki kadrov dlya tsifrovoy ekonomiki $\mathrm{v}$ Rossii], in Proceedings of the II All-Russian SC with the international participation "The tendencies of development of Internet and digital economy" [Tendentsii razvitiya internet $\mathrm{i}$ tsifrovoy ekonomiki], 2019. pp. 13-15. (In Russ.).

[12]M. Olssen, M. Peters, "Neoliberalism, higher education and the knowledge economy: From the free market to knowledge capitalism", Journal of Education Policy, 2005, vol. 20.3, pp. 313-345.

[13] A.G. Burda, G.P. Burda, "Trends in Research on Economic Cybernetics and Digital Economy" [Perspektivy izucheniya ekonomicheskoy kibernetiki i tsifrovoy ekonomiki], Higher Education in Agricultural HEI: Problems and Trends: collection of articles on results of educational-methodological conference [Vyssheye obrazovaniye $\mathrm{v}$ agrarnom vuze: problemy i perspektivy: sbornik statey po materialam uchebno-metodicheskoy konferentsii], 2018, pp. 234-237. (In Russ.).

[14] A.E. Vorobyov, A.K. Murzayeva, "Role of university departments in management of innovations in educational process", Pedagogical Education in Russia, 2017, vol. 10, pp. 17-22. (In Russ.). DOI: 10.26170/po17-1003 